\title{
The Effect of Earnings Management on Company's Performance with Audit Quality and Company's Size as Moderating Variables
}

\author{
Aprih Santoso ${ }^{\bowtie}$, Rahmatya Widyaswati \\ Fakultas Ekonomi Universitas Semarang \\ e-mail: aprihsantoso07@gmail.com
}

\begin{abstract}
The purpose of this study was to see how the effects of earnings management on the performance of companies with audit quality and size of the company as a moderating variable. High Quality Audit demonstrated with large or small public accounting firm. The size of the company can be seen from how many assets owned by the company itself. The sample in this study is based on purposive sampling, with specific criteria that a manufacturing company listed on the Stock Exchange during the period 2011-2014 which publishes annual financial statements (annual report) in complete accordance with the measurement variables to be studied in this research, manufacturing company whose financial statements are audited by KAP Big 4 and nonBig 4. So in the get the 22 companies audited by the Big 4 accounting firm and the 28 companies audited by KAP Non Big 4. The results of this study variable Profit Management significant negative effect on the performance effect Perusahaan. VariabelCompany's Size significantly strengthen the positive relationship between Profit Management with Corporate performance. Variable Audit Quality significant positive effect strengthens the relationship between the Profit Management with Corporate Performance.
\end{abstract}

Keywords: earnings management, corporate performance, quality audit, company's size

\begin{abstract}
Abstrak
Tujuan dari penelitian ini adalah untuk melihat bagaimana pengaruh manajemen laba terhadap kinerja perusahaan dengan kualitas audit dan ukuran perusahaan sebagai variabel moderasi. Kualitas audit tinggi ditunjukkan dengan kantor akuntan publik besar atau kecil. Ukuran perusahaan dapat dilihat dari berapa banyak aset yang dimiliki oleh perusahaan itu sendiri. Sampel dalam penelitian ini didasarkan pada purposive sampling, dengan kriteria khusus yaitu perusahaan manufaktur yang terdaftar di Bursa Efek selama periode 2011-2014 yang menerbitkan laporan keuangan tahunan dengan lengkap sesuai dengan variabel pengukuran dalam penelitian. Perusahaan manufaktur yang laporan keuangannya diaudit oleh KAP Big 4 sejumlah 22 perusahaan, dan non-Big 4 sejumlah 28 perusahaan. Hasil penelitian menunjukkan variabel manajemen laba berpengaruh negatif signifikan terhadap efek kinerja Perusahaan. Variabel ukuran perusahaan secara signifikan memperkuat hubungan positif antara manajemen laba dengan dengan kinerja perusahaan. Variabel kualitas audit berpengaruh positif signifikan dan memperkuat hubungan antara manajemen laba dengan kinerja perusahaan.
\end{abstract}

Kata Kunci: manajemen laba, kinerja perusahaan, kualitas audit, ukuran perusahaan 


\section{INTRODUCTION}

Financial statement is something important for the company. Financial statement shows the results of the company's performance and is the management accountability to the company's owner. Based on the financial statement, the company's performance is usually assessed based on the income earned by the company. Therefore information on the company's earnings is important and often manipulated so that financial statements no longer reflect the actual condition of the company.

According to Statement of Financial Accounting Concept (SFAC) No. 1, earnings information is a major concern to estimate the performance or accountability of the management. Earning also helps owners to measure the company's earning power in the future. The awareness of management in generating earnings can lead to deviant behavior by managers in order to produce earning. This deviant effort is commonly called earnings management.

Earnings management is a way of presenting the earnings that aims to maximize the utility of management and or to increase market value through the selection of accounting procedures policy set by the management (Scott, 2012). According to Roychowdhury (2006) management can perform earnings management through activity that actually deviates from normal business, but it is seemed appropriate with the company's normal operations. In the Roychowdhury's research, it is found that executives are more likely to set the eranings through real earnings management than through accrual earnings management, since the manipulation of accrual earnings management is likely to attract auditors, investors and regulators (government agency).

Management actions to perform earnings management will reduce the reliability of reported earnings (Scott, 2012), so that can reduce the quality of earnings because earnings reports are submitted not in accordance with the actual condition. To convince, the owners can conduct an audit so that the owners sure that their financial statements are qualified and can be used as a basis for decision making.

Qualified audit can affect the level of the financial statements users' trust. This is in line with the research conducted by Becker et al. (1998) which studied the effect of audit quality on earnings management. High quality audit was indicated by an audit conducted by KAP Big 6 and KAP non Big 6. Supported by Jiang (2010) and Gerayliet al. (2011) it showed that audit quality affected negatively on earnings management intensity. The higher audit quality, the lower the earnings. On the other hand Piot and Janin (2005) in their research indicated that audit quality had no significant relationship with earnings management. The company audited by KAP Big 5 did not show low earnings management.

According to Fitriyani et al. (2012) in their research, to get earnings management throughaccrualactivities willhavemoreeffects on the company's performance compared to earnings management through real activities and audit quality can not moderate the effect of earnings management both accrual and real on company's performance. While the study conducted by Charles et al. (2010) stated that auditor client of Big Four had lower level of earnings management than auditor client of non Big Four.

Herawaty (2008) also showed that earnings management may be weakened by an audit conducted by Big 4 and audit quality moderated earnings management and company's value. Furthermore, Chen et al. (2011) examined the effect of audit quality on earnings management and cost of equity capital. Audit quality was shown by the companies audited by KAP top 8 and KAP non-top 8 . The results showed that audit 
quality could affect the relationship between earnings management and cost of equity capital.

Based on the description above, this study was conducted to see the effect of earnings management on company's performance with audit quality and company;s size as moderating variables. In this study, the audit quality was expected to be able to affect the potential occurrence of earnings management, and therefore could also affect the company's financial performance.

\section{Agency Theory}

Agency theory explains the existence of contractual relationship between a principal or more binding agent to perform several services on behalf of the principal which includes delegation of authority to an agent to make decisions. If both parties maximize the collective interest, then there is a good reason that the agent will not always perform action in accordance with the purposes of the principal (Jensen and Meckling, 1976). Conflict of interest between the companies' owners and management is increasing since the owner of the company can not monitor the daily activities of managers to ensure that managers act in accordance with the wishes of the the companies' owners.

\section{The Effect of Earnings Management on Company's Performance}

According to Wang (2013) earnings management is one of the factors that affect the company's performance. Management will choose a particular method to get profit in accordance with the motivation. This will affect the quality of the performance reported by management (Gideon, 2005). While Gunny's research (2005) found that real earnings management would have negative effect on future operating performance. Real earnings management actions in the short term showed good company's performance, but in the long term it would harm the company. Afriyenti's research (2009) examined the effect of real earnings management and accrual earnings management on company's performance. Her research result showed that real earnings management affected the company's performance but not with accrual earnings management. According to Ujianto and Pramuka (2007) Earnings Management did not significantly affect company's performance. Based on the foregoing, the researcher formulated hypothesis as follows:

H1: It was assumed that earnings management gave significant negative effect on company's performance.

The Effect of Company's Size on Earnings Management and Company's Performances.

The company's size can be seen from the total assets of the company, the greater the assets owned by the company, the greater the company's size. Watt and Zimmerman (1978) tried the positive accounting theory that compute large companies tend to invest their funds into the projects that had lower variant. According to Trilestari and Yulimar (2012) the company's size affected earnings management. Meanwhile, according to Rosena, Mulyani and Prayogo in their research stated that company's size did not moderate the effect of audit quality on earnings management.

H2: It was assumed that company's size strengthened the relationship between earnings management and company's performance.

\section{The Effect of Audit Quality on Relation- ship between Earning Management and Company's Performances.}

Earnings Management shows the reliability and the credibility of financial statements so it makes the financial statements need to be audited. High audit quality can be seen from the magnitude of KAP. The great 
KAP has great resource to improve audit quality, so it can affect the actions of earnings management conducted by the management (Dopuch and Simunic, 1982; Beckerm, 1998; Ardiati, 2003; Herawaty, 2008; and Chen et al. 2011).

H3: It was assumed that Audit Quality (AQ) strengthened the relationship between Earnings Management (DA) and Company's Performance (ROA). to achieve the expectations of investors, debt contract motivation, and IPO (Initial Public Offering) motivation. Meanwhile, according to Bryshaw and Eldin (1989) the reasons of management conducting earnings management are: (1) management compensation schemes linked to company's performance presented in the reported accounting profit; and (2) fluctuations in management performance can lead to owners intervention to replace the management

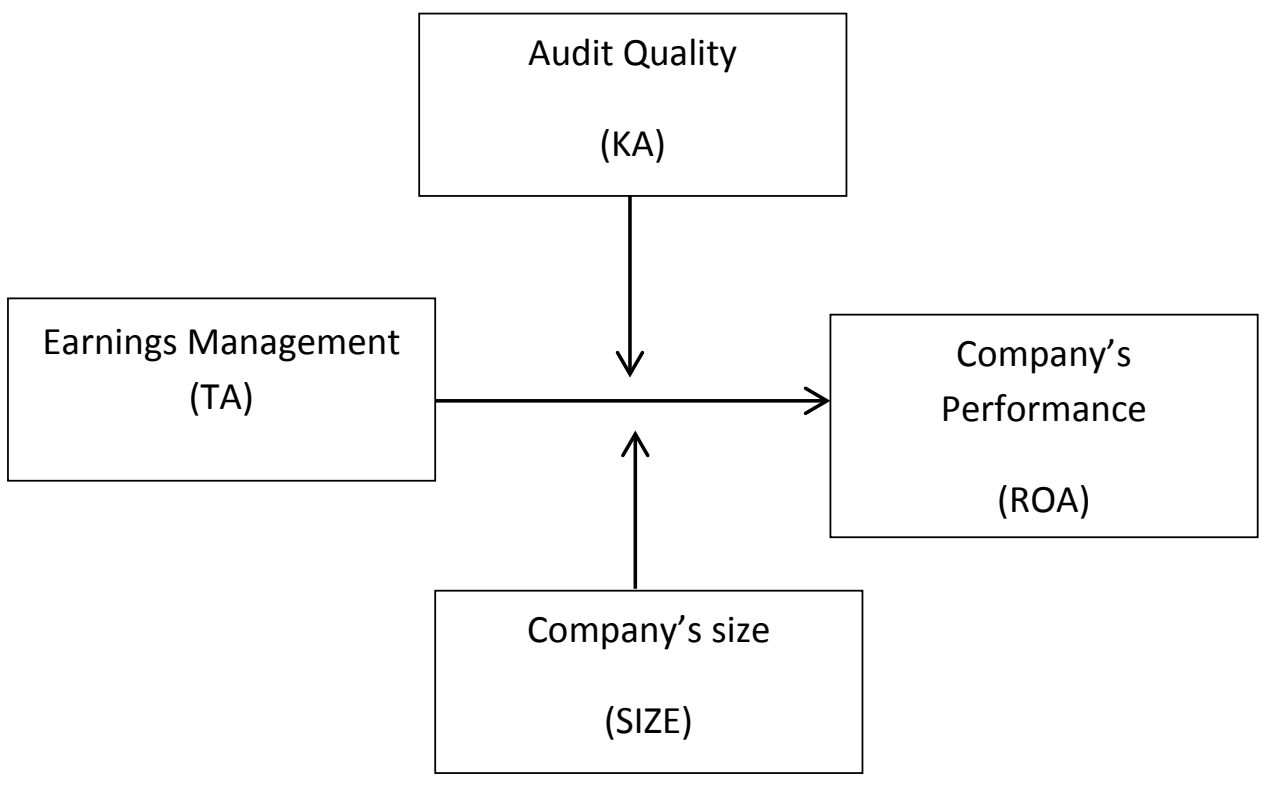

Figure 1. Conceptual Framework

\section{Earnings Management}

Earnings management is as a process of taking deliberate steps within the limits of generally acceptable accounting principles both within and outside the limits of General Accepted Accouting Principles (GAAP). While Scott (2012) defines earnings management as a way of presenting the profit that aims to maximize the utility of management and or to increase market value through the selection of accounting procedures policy set by the management. According to Scott (2012) there were some motivations to perform earnings management, namely: bonus program motivation, the motivation by direct takeover. Earnings management conducted by managers in the financial statements will affect the company's financial performance, which hereafter will affect the stock's performance (Harris, 2004).

\section{Company's Performances}

According to Moerdiyanto (2010), company's performance is the result of a series of business processes in which by the sacrifice of many kinds of resources that could be human resources or company's financial. If the company's performance increases, the activities of the company will also increase so that resulting in earnings for the company. 
While according to Chariri and Ghozali (2011), the company's performance can be measured by using financial information or non financial information. Non-financial information can be in the form of customer's satisfaction with the services provided by the company.

The company's performance is affected by several factors, among others, the concentrated or not concentrated ownership, earnings manipulation, as well as the disclosure of financial statements. According to Wang (2013), earnings management is one of the factors that affect the company's performance. Management will choose particular method to get profit in accordance with motivation.

\section{Company's Size}

Siregar and Utama (2005) in Pujiningsih (2011) said that the bigger the company's size, usually the available information for investors in making decisions with respect to investments in the company's stock is getting more and more. According to Ferry and Jones (in Sujianto, 2001), the company's size described the big or small of company represented by total assets, number of sales, the average of total sales and the average of total assets. According to Nuryaman (2008) large-sized companies had base of wider interest holders, so that various policies of large companies would have greater impact on public interest compared to small companies.

Unlike the case with research conducted by Carolina and Juniarti (2005) in Abiprayu (2011), which stated that small company would tend to conduct the practice of smoothing earnings compared to large companies, because large companies tend to get more attention from analysts and investors compared to small companies.

\section{Audit Quality}

Watkins et al. (2004) had identified four definitions of audit quality from some experts, namely as follows.

a. Audit quality is the probability of the market assessment that the financial statements contain material errors and auditors will find and report the material errors.

b. Audit quality is the probability that the auditor will not report an audit report with common opinion without exception on the financial statements containing the material errors.

c. Audit quality is measured from the accuracy of the information reported by the auditor.

d. Audit quality is determined from the audit capabilities to reduce noise and bias as well as to improve the purity on accounting data.

Krishnan (2003) showed that the companies audited by KAPBig 6 had earnings management (discretionary accruals) lower than companies that were not audited by KAP Big 6. The study of Gerayli et al. (2011) showed that high audit quality of KAP Big 4 could affect earnings management than the audit conducted by KAP non-Big 4 .

\section{METHOD}

The populations in this research were manufacturing companies listed in Indonesia Stock Exchange of 2011 - 2014 periods. The sample taking used in this research is purposive sampling with certain criteria (Ghozali, 2011). The sample criteria in this study are:

1. The manufacturing companies listed in Indonesia Stock Exchange during the period of 2011-2014 which publish annual financial statements (annual report) complete in accordance with the variables measurement to be studied in this research. 
2. Manufacturing companies whose financial statements are audited by KAP Big 4 and KAP Non Big 4. The researcher got 22 companies audited by KAP Big 4 and 28 companies audited by KAP non-Big 4 . The researcher got sample of 200 companies.

\section{Operational Variables}

\section{Earnings Management}

Earnings management in this study was the one proxied with discretionary total accrual. The model used to measure earnings management in this study was the modification of Jones' model, because this model was considered better among the other models to measure earnings management as this model divided between non discretionary accrual and discretionary accrual. Discretionary total accrual was calculated by using Modified Jones' Models (Dechow, 1995 cited by Mediastuti and Mas'ud, 2003):

a. Total Accruals (TA)

$\mathrm{TA}=\frac{\mathrm{NI}_{\mathrm{t}}-\mathrm{CFO}_{\mathrm{t}}}{\mathrm{A}_{\mathrm{it}-1}}$

as follows:

$\mathrm{TA}=$ Total Accruals in company $\mathrm{i}$ on $\mathrm{t}$ years

$\mathrm{NI}_{\mathrm{t}}=$ Net Income in company $\mathrm{i}$ on $\mathrm{t}$ years

$\mathrm{CFO}_{\mathrm{t}}=$ Cash Flow Operation in company $\mathrm{i}$ on $\mathrm{t}$ years

$\mathrm{A}_{\mathrm{it}-1}=$ Total Assetsin $\mathrm{i}$ company years before $\mathrm{t}$

b. Diskresioner Total Accruals (DA)

$\mathrm{DA}_{\mathrm{t}}=\frac{T A_{t}}{\text { Sales }_{\mathrm{t}}}-\frac{T A_{0}}{\text { Sales }_{0}}$

Where :

$\mathrm{DA}_{\mathrm{t}}=$ Discretionary Accruals on $\mathrm{t}$ y ears

$\mathrm{TA}_{\mathrm{t}}=$ Total Accruals on $\mathrm{t}$ years

Sales ${ }_{t}=$ Sales on $t$ years

$\mathrm{TA}_{0}=$ Total Accruals on base year

Sales $_{0}=$ Sales on base y ear

\section{Company's Performance}

The performance offinancial companies is measured using return on assets (ROA). ROA is obtained by dividing the net earnings after taxes by total assets.
$R O A=\frac{\text { Net Profit }}{\text { Total Assets }} x 100 \%$

\section{Audit Quality}

Audit quality in this study was measured using proxy of KAP size which was divided into KAP big four and KAP non big four. KAP big four was given number 1, while the one using KAP non big four was given number 0 . In Indonesia, KAP included in Big Four are:

a. Tanudiredja, Wibisana \& Partners, affiliated with Price water house Coopers.

b. Purwantono, Suherman \& Surja, affiliated with Ernst \& Young

c. Osman Bing Satrio \& Partners, affiliated with Delloite

d. Siddharta \& Widjaja, affiliated with KPMG

\section{Company's Size}

Comany's size was measured by using logaritma natural from total assets, (Budiasih, 2009).

Company's Size $($ SIZE $)=$ Ln Total Assets

\section{RESULT AND DISCUSSION}

\section{Descriptive statistics}

Based on descriptive statistic such as the numbers of sample, average sample (Mean), and standard deviation for each variable, as follows:

Table1. Descriptive Statistic Descriptive Statistics

\begin{tabular}{lccc}
\multicolumn{4}{c}{ Descriptive Statistics } \\
& Mean & $\begin{array}{c}\text { Std. } \\
\text { Deviation }\end{array}$ & N \\
\hline ROA & 9.4789 & 10.05602 & 200 \\
TA & .2771 & .45090 & 200 \\
\hline
\end{tabular}

Source: Secondary data which is processed

According to the table above, which 
summarises the results from descriptive statistic data, 9.4789 the average of company's performance (ROA) and 0.2771 earnings management (TA)

\section{Normality Test}

Normality test aims to test the regression, the dependent variables and the independent variables. Both are distributed normaly. The normality test in this study used histogram graphical analysis and Normal Probability Plot.

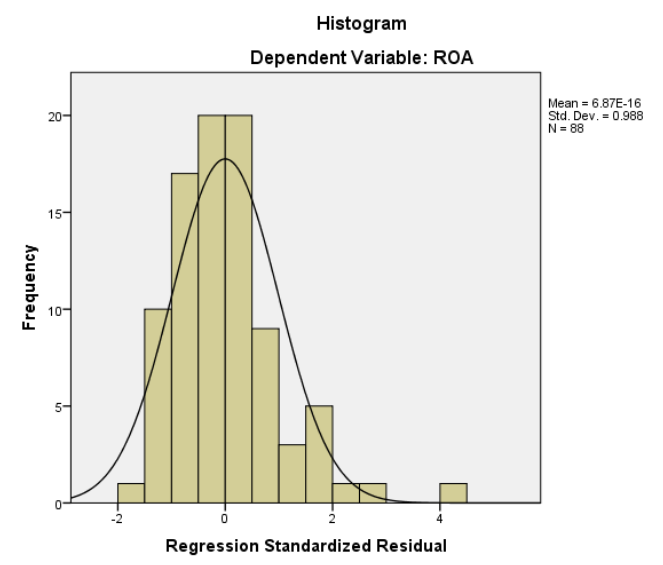

Figure 2. Histograms (Left)

Source: Secondary data which is processed

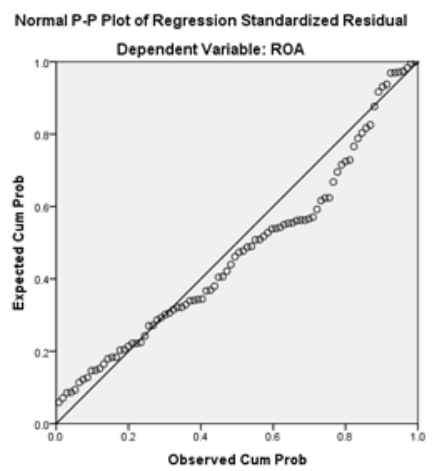

Figure 3. P-P Plots (Right)

Source : Secondary data which is processed

\section{Autocorrelation Test}

Test Autocorrelation in this study ran with Durbin Watson Test. The result of the test found that DW was 2.174. The score of DW was bigger than the upper limitation
1.788. It shows there is no autocorrelation on model.

Tabel 2. Uji Durbin Watson

\begin{tabular}{cc}
\hline Model & Durbin-Watson \\
\hline 1 & 2.174 \\
\hline Source: Secondary data which is processed
\end{tabular}

\section{Coefficient of Determination}

Table 3. Test Result $\mathbf{R}^{\mathbf{2}}$ dan Adjusted $\mathbf{R}^{2}$

Model Summary ${ }^{b}$

\begin{tabular}{lcllc}
\hline Model & $\mathbf{R}$ & $\begin{array}{c}\mathbf{R} \\
\text { Square }\end{array}$ & $\begin{array}{c}\text { Adjusted } \\
\text { R Square }\end{array}$ & $\begin{array}{c}\text { Std. Error } \\
\text { of the } \\
\text { Estimate }\end{array}$ \\
\hline 1 & $.446^{\mathrm{a}}$ & .198 & .186 & 9.07157 \\
\hline
\end{tabular}

Source: Secondary data which is processed

Based on the tableabove, the result of test was 0.198. It means that independent variables such as earnings management, earnings management*company's performance, earnings management*company's size were able to explain $9.8 \%$ variation from dependent variable of company's performance, mean while the rest of $80.2 \%$ can be explained by the other factor which was not include on model.

\section{Multicolinearity Test}

Multicolinearity shows that free variable has a very strong direct relationship (correlation) between one another. Multicolinearity happened if their interactions have a higher VIF score of 10 or tolerance score less than 0.10 . Multicolinearity test can be seen on the table below:

Table 4. The Result of Multicolinearity Test

\begin{tabular}{llll}
\hline & $\begin{array}{c}\text { Model } \\
\text { Tolerance }\end{array}$ & \multicolumn{2}{c}{$\begin{array}{c}\text { Collinearity Statistics } \\
\text { VIF }\end{array}$} \\
\hline 1 & (Constant) & & \\
& TA & .008 & 118.015 \\
& MODERAT1 & .009 & 110.388 \\
& MODERAT2 & .411 & 2.432 \\
\hline
\end{tabular}

Source: Secondary data which is processed 


\section{Hypothesis Test Results and Discussion}

Table 5. Coefficients Test Results

\begin{tabular}{llccccccc}
\multicolumn{1}{c}{$\begin{array}{c}\text { Model } \\
\text { B }\end{array}$} & \multicolumn{2}{c}{$\begin{array}{c}\text { Unstandardized } \\
\text { Coefficients }\end{array}$} & $\begin{array}{c}\text { Coefficients }^{\mathbf{2}} \\
\text { Standardized } \\
\text { Coefficients }\end{array}$ & $\mathbf{t}$ & \multicolumn{2}{c}{$\begin{array}{c}\text { Sig. } \\
\text { Tolerance }\end{array}$} & \multicolumn{2}{c}{$\begin{array}{c}\text { Collinearity } \\
\text { Statistics } \\
\text { VIF }\end{array}$} \\
\hline 1 & Std. Error & Beta & & & & & & \\
& (Constant) & 7.627 & .763 & & 9.991 & .000 & & \\
& TA & -55.279 & 15.493 & -2.479 & -3.568 & .000 & .008 & 118.015 \\
& MODERAT1 & 3.938 & 1.098 & 2.410 & 3.587 & .000 & .009 & 110.388 \\
& MODERAT2 & 12.567 & 2.594 & .483 & 4.844 & .000 & .411 & 2.432 \\
\hline
\end{tabular}

Source: Secondary data which is processed

Hypothesis 1 Test: The Effect of Earnings Management on Company's Performances.

This study hypothesized Earnings Management gave significant negative effect on Company's Performance. Based on the multiple linear regression test, it indicated $\alpha=$ 0.05 earnings management with significancy level of 0.000 . This showed earnings management gave significant negative effect on company's performance showed by $\mathrm{t}=$ - 3.568. The results of this study indicated that the practice of earnings management could not affect company's performance, because good company would try to reduce the practice of earnings management.

Hypothesis 2 Test: The Effect of Company's Size on the Relationship Between Earnings Management and Company's Performance.

The second hypothesis stated that Company's Size gave significant positive effect on the relationship between Earnings Management and Company's Performances. From the above table, Company's Size had coefficient value of 3.587 with significancy level of 0.000 less than 0.05 . The results of this study indicated that Company's Size could moderate Earnings Management and Company's Performance.

Hypothesis 3 Test: The Effect of Audit Quality on the Relationship between Earnings
Management and Company's Performances. The third hypothesis stated that Audit Quality gave significant positive effect on the relationship between Earnings Management and Company's Performances. This showed that Audit Quality could moderate between Earnings Management and Company's Performances. The financial statements audited by KAP could guarantee more qualified audit results because the audit quality was considered able to improve the quality of financial reports, thereby reducing the occurrence of earnings management.

\section{CONCLUSION AND RECOMMENDA- TION}

Based on this study, it could be concluded as follows:

1. Earnings Management Variables gave significant negative effect on Company's Performance.

2. Company's Size Variables gave significant positive effect, strengthening the relationship between Earnings Management and Company's Performances.

3. Audit Quality Variables gave significant positive effect, strengthening the relationship between Earnings Management and Company's Performances. 
The results of this study are expected to provide benefits to the management with regard to the company's performance by taking into account the company's size and the audit quality. Company's size can affect the company's performance so that company should further improve the company's performance related to audit quality. With high audit quality, it is expected to be able to reduce earnings management and to improve investor's confidence.

This study was limited to the use of Earnings Management variables, Company's Performance, Audit Quality and Company's Size. In measuring Audit Quality, the researcher only used the size of KAP big four and non big four. This research only used the sample of manufacturing company and short time span.

Based on the study's limitation, there are some things to consider in the future research, namely: 1) The addition of other variables that have not been included, 2) It is necessary to use other proxies as measurer of Audit Quality, 3) The need for the addition of sample or sample usage apart from manufacturing companies, and 4) Adding longer time span.

\section{REFERENCES}

Afriyenti, Mayar. 2009. Pengaruh Accrual Earnings Management dan Real Earnings Management Terhadap Kinerja Perusahaan dengan Struktur Kepemilikan Sebagai Variabel Moderasi: Studi Empiris Di BEI. Tesis. Program Pascasarjana Universitas Gadjah MadaYogyakarta.

Becker, C.L.M.L Defond, J. Jiambalvo, K.R Subramanyam. 1998. The Effect of Audit Quality On Earnings Management. Contemporary Accounting Research. Vol.15, 1-24
Bryshaw, R. E dan Ahmed Eldin. 1989. The Smoothing Hipothesis and The Role of Exchange Differences. Journal of Business, Finance, and Accounting. 621-633

Chen et al., 2010. Are Family Firms More Tax Aggressive Than NonFamily Firms? Journal of Financial Economics, 41-61

Dechow, P.M. 1994. Accounting Earning and Cash Flow as Measures of Firm Performance: The Role of Accounting Accruals. Journal of Accounting and Economics. Vol.18, 3-42

Dyreng, et al., 2010. The Effect of Executives on Corporate Tax Avoidance. The Accounting Review. Vol. 85, 11631189.

Fitriyani, D, Prasetyo.E, Mirdah A, dan Putra.W.E. 2012. Pengaruh Manajemen Laba terhadap Kinerja Perusahaan dengan Kualitas Audit Sebagai Variabel Pemoderasi. Simposium Nasional Akuntansi VIII Solo

Gerayli, Muhdi Safari, Abolfazl MomeniYaanosari, and Ali Reza Ma'atoofi. 2011. Impact of Audit Quality on Earnings Management (Evidence From Iran). International Research Journals of Finance and Economics, issue 66.

Ghozali, Imam, 2011. Aplikasi Analisis Multivarite dengan Program IBM SPSS 19 (Edisi Kelima). Universitas Diponegoro Semarang.

Herawaty, Vinola. 2008. Peran Praktek Corporate Governance sebagai Moderating Variable dari Pengaruh Earnings Management terhadap Nilai Perusahaan. Simposium Nasional Akuntansi 11. Pontianak.

Jiang, J., Petroni, K. R., \& Wang, I. Y. 2010. CFOs and CEOs: Who Have the Most 
Influence on Earnings Management? Journal of Financial Economics (JFE), Vol. 96, No. 3, 513 - 526

Man, C.K., \& Wong, B. 2013. Corporate Governance And Earnings Management: A Survey. The Journal of Applied Business Research, Vol. 29, No.2, 391-418

Nuryaman. 2008. Pengaruh Konsentrasi Kepemilikan, Ukuran Perusahaan dan Mekanisme Corporate Governance Terhadap Manajemen Laba. Simposium Nasional Akuntansi $X I$. Pontianak.

Pallant, J. 2011. A Step by Step Guide to Data Analysis using SPSS. Crows Nest NSW: Allen and Unwin.

Piot,C. and R. Janin. 2005. Audit Quality and Earnings Management in France. Working Papers.

Rosena, A. D., Mulyani, S. D., \& Prayogo, B. 2016. Pengaruh Kualitas Audit Dan Leverage Terhadap Manajemen Laba dengan Ukuran Perusahaan Sebagai Variabel M o d e rasi . Jurnal Magister Akuntasi Trisakti (e-Journal), 21-42
Scott, W. R. 2012. Financial Accounting Theory. 6th edition. Toronto: Pearson Education Canada

Subramanyam, K.R. dan Wild, Jhon J. 2010. Analisis Laporan Keuangan. Salemba Empat. Jakarta.

Tangjitprom, N. 2013. The Role of Corporate Governance in Reducing the Negative Effect of Earnings Management. International Journal of Economics and Finance Vol.5, No.3, 41-45

The Statement of Financial Accounting Concept (SFAC) No.1. 1978. Financial Accounting Standards Board (FSAB).

Wang, J.L., Sheu, H.J., \& Chung, H. 2011. Corporate Governance Reform and Earnings Management. Investment Management and Financial Innovations, 8(4).

Watkins. Ann L, Hillison, William, Morecroft, Susan E. 2004. Audit Quality: A Synthesis Of Theory and Empirical Evidence. Journal of Accounting Literature, Vol 23, 153-193. 